\title{
Impact of Drip Irrigation Levels on Pigeon Pea Based Intercropping Systems with Pulses in Malaprabha Command Area
}

\author{
H. N. Anandkumar*, S. C. Alagundagi, G. B. Shashidhara and V. B. Kuligod \\ Department of Agronomy, College of Agriculture, Dharwad University of Agricultural \\ Sciences, Dharwad-580005, Karnataka, India \\ *Corresponding author
}

K e y w o r d s
Pigeon pea,
Intercropping,
Green gram, Black
gram, Drip
irrigation, Yield and
water use efficiency
Article Info
Accepted:
18 August 2020
Available Online:
10 September 2020

\section{A B S T R A C T}

A field experiment was conducted to study the "Drip irrigation levels on pigeon pea based intercropping systems with pulses in Malaprabha command area" under a vertisol at the Irrigation Water Management Research Centre, Belvatagi Dharwad during kharif2017. The experiment was laid out under strip plot design with three replications, comprising treatments of two drip irrigations levels (70\% and $50 \% \mathrm{PE}$ ) and three intercropping systems viz., pigeon pea + green gram (1:3) and black gram (1:3) and sole pigeon pea along with rainfed sole pigeon pea (control). Drip irrigation provided at 70 per cent PE recorded higher pigeon pea seed yield $\left(2,010 \mathrm{~kg} \mathrm{ha}^{-1}\right)$ compared to at 50 per cent PE $(1,997$ $\left.\mathrm{kg} \mathrm{ha}^{-1}\right)$. Among the intercropping systems, sole pigeon pea under drip recorded higher seed yield $\left(2,126 \mathrm{~kg} \mathrm{ha}^{-1}\right)$ followed by pigeon pea intercropped with blackgram or greengram at $1: 3$ row ratio (1,986 and $1,898 \mathrm{kgha}^{-1}$, respectively). Interaction effect of drip irrigation at 70 per cent PE with sole pigeon pea recorded higher seed yield $\left(2,198 \mathrm{~kg} \mathrm{ha}^{-1}\right)$ followed by drip irrigation at 50 per cent PE with sole pigeon pea $\left(2,053 \mathrm{~kg} \mathrm{ha}^{-1}\right)$ and pigeonpea intercropped with blackgram at 1:3 rowratio $\left(2,047 \mathrm{kgha}^{-1}\right)$. Rainfed sole pigeon pea recorded lower seed yield $\left(1,613 \mathrm{~kg} \mathrm{ha}^{-1}\right)$. Irrespective of drip irrigation level of 50 or 70 per cent PE, pigeonpea + blackgram or greengram at 1:3 row intercropping system recorded significantly higher pigeon pea seed equivalent yield $\left(3,412\right.$ and $3,421 \mathrm{~kg} \mathrm{ha}^{-1}$, respectively). Higher water use efficiency was recorded under drip irrigation provided at 50 percent PE in pigeonpea intercropped with greengram $(1: 3)\left(5.48 \mathrm{kgha}^{-1}-\mathrm{mm}\right)$ and lower was with rainfed sole pigeonpea $\left(3.06 \mathrm{kgha}^{-1}-\mathrm{mm}\right)$.

\section{Introduction}

Land for agriculture activities is decreasing day by day as it is being put to nonagricultural purposes. It is rather inevitable to accommodate production through existing crops or cropping systems. Time and space utilization in agriculture through intercropping systems is one of the options available for increasing production (Sankaran and Rangasamy, 1990).

Pulses are one of the basic ingredients in Indian diet and excellent feed and fodder for livestock. Pulses are endowed with the unique ability of biological nitrogen fixation, carbon sequestration, soil amelioration, low water requirement and capacity to withstand harsh 
climate. Pulses have remained an integral component of sustainable crop production systems since time immemorial, especially in the dry areas. They also offer good scope for the crop diversification and intensification. Though pulses are protein rich crops, they are still being cultivated in more than 78 per cent of the energy starved rainfed condition.

Pigeonpea (Cajanus cajan L. Millsp.) is one of the important and protein rich seed legumes of semi-arid tropics grown throughout the tropical and subtropical regions of the world. In India, it is being grown on an area of $5.33 \mathrm{mha}$ with a production of $4.18 \mathrm{mt}$ and productivity of $913 \mathrm{~kg}$ per ha (Anon., 2017). Only 4.5 percent of pigeonpea area is irrigated. The productivity can be improved by adopting suitable agro-techniques such as using early maturity high yielding varieties coupled with scientific irrigation management including micro irrigation.

Greengram (Vigna radiate L.) is also one of the important pulse crops in India. It is grown on an area of $4.32 \mathrm{~m}$ ha with a production of $1.95 \mathrm{~m} \mathrm{t}$ and productivity of $500 \mathrm{~kg}$ per ha (Anon., 2017). Black gram (Vigna mungo L.) is another important pulse grown in India. It is cultivated on an area of $4.47 \mathrm{~m}$ ha with a production of $3.28 \mathrm{~m} \mathrm{t}$ and productivity of $632 \mathrm{~kg}$ per ha (Anon., 2017). These are short duration crops with lower water requirement and soil fertility. Being short duration crops, they also fit well in various multiple and intercropping systems.

In Malaprabha command areas, maizechickpea is the common sequence cropping system followed under delayed release of canal water during August end or first fortnight of September resulting in delayed sowing of rabi crops leading to lower yields. With early receipt of rains during kharif, the pulses viz., greengram, blackgram and pigeonpea are sown. But due to long dryspells, crops suffer from moisture stress resulting in poor yields. Hence, to over come these problems, less water requiring pulses viz., green gram and black gram can be intercropped with pigeon pea under drip irrigation to utilize the stored water from farm ponds etc., more economically which is the better option during kharif in this command area. Not much research work on these aspects has been carried out on pigeonpea based cropping systems under drip irrigation especially in Northern Karnataka. Keeping these points in view, the present investigation was planned.

\section{Materials and Methods}

A field experiment entitled "Drip irrigation levels on pigeon pea based intercropping systems with pulses in Malaprabha command area" was conducted during kharif2017-18 at Irrigation Water Management Research Centre (IWMRC), Belvatagi, Navalagund, Karnataka. The experiment was laid out under strip plot design with three replications, comprising treatments of two drip irrigations levels (70 \% and $50 \%$ PE) and three intercropping systems viz., pigeon pea + green gram (1:3) and black gram (1:3) and sole pigeon pea along with rainfed sole pigeon pea (control). The soil of the experiment plot was vertisol (Blacksoil). The dripperline (laterals) were spaced at $60 \mathrm{~cm}$ distance in intercropping system and in sole pigeonpea spaced at $120 \mathrm{~cm}$ distance and inner line drippers were spaced at the distance of $40 \mathrm{~cm}$ with 4 liter discharge per hour. The seed rate of pigeon pea, green gram and black gram used was $12.00,8.25$ and $9.90 \mathrm{~kg}$ per ha, respectively and sown as per the treatments. The sowing was carried out on $10^{\text {th }}$ June, 2017 and recommended fertilizers were applied at the time of sowing $5 \mathrm{~cm}$ deep and $5 \mathrm{~cm}$ away from the seed line and covered with soil. All cultural practices were adapted as per recommendation. Irrigation was provided on the basis of Pan Evaporation (PE) at 7 days 
interval. The rainfall received during the cropping period of green gram was $49.2 \mathrm{~mm}$, black gram was $74.4 \mathrm{~mm}$ and pigeonpea was $527.6 \mathrm{~mm}$ at different phenological stages. The crops are harvested at physiological maturity. The experimental data were statistically analyzed using MSTAT-C programme (for pigeon pea) and the level of significance used was $P=0.05$. Intercrop data were analyzed using ' $t$ ' test with level of significance at 5 per cent.

\section{Results and Discussion}

\section{Growth and yield of intercrops}

Drip irrigation provided at 70 or 50 percent PE did not influence significantly the growth and yield in intercropped legumes (Table 1). However, numerically higher pods per plant and seed yield per plant were recorded with drip irrigation scheduled at 70 percent PE to greengram (17.3 and $11.8 \mathrm{~g}$ plant $^{-1}$, respectively) and to black gram (32.1 and $11.5 \mathrm{~g} \mathrm{plant}^{-1}$, respectively). Green gram and black gram recorded numerically higher seed yield when drip irrigation was provided at 70 percent PE $\left(1,474\right.$ and $1,411 \mathrm{~kg} \mathrm{ha}^{-1}$, respectively) compared to drip irrigation given at 50percent PE $(1,440$ and $1,374 \mathrm{~kg}$ ha ${ }^{1}$, respectively). It is due to fact that both the crops were of short duration and their requirement of water is less for the growth. Moisture variation was not much in rhizosphere of the crops and also it may be due to the 49.2 and $74.4 \mathrm{~mm}$ of rainfall received during growing period of green gram and black gram, respectively, so the effect of drip irrigation was nullified. These results were in conformity with Parmar and Thanki (2007).

\section{Effect of drip irrigation levels on growth and yield of pigeon pea}

Growth and yield parameters of pigeon pea did not differ significantly due to drip irrigation levels (Table 2). However, ranges were viz., for plant height (233.8 to $232.2 \mathrm{~cm})$, total drymatter production (277.5 to $271.4 \mathrm{~g}$ plant $\left.^{-1}\right)$, number of pods per plant (166.7 to 165.2), seed yield (52.8 to $51.9 \mathrm{~g} \mathrm{plant}^{-1}$ ) and seed yield (2,010 to $\left.1,997 \mathrm{~kg} \mathrm{ha}^{-1}\right)$. Pigeon pea equivalent yield ranged from 2,982 to $2,933 \mathrm{~kg} \mathrm{ha}{ }^{-1}$. Non significant differences with respect to growth and yield of pigeon pea due to the level of drip irrigation. May be due to fact that at grand growth period of pigeon pea, higher rainfall was received and higher moisture content was present in rhizosphere so that the effect of drip irrigation was not observed at 70 and 50 per cent PE. Similar results were recorded by Solanki et al., (2010) and Mahalakshmi et al., (2011).

\section{Effect of intercropping on growth and yield of pigeon pea}

Drip irrigation provided at 70 or 50 percent PE did not influence significantly the growth and yield of pigeon pea (Table 2). However, for intercropping, numerically higher seed yield $\left(2,126 \mathrm{~kg} \mathrm{ha}^{-1}\right)$ was recorded with sole pigeon pea followed by pigeon pea intercropped with black gram at 1:3 row ratio intercropping system $\left(1,986 \mathrm{~kg} \mathrm{ha}^{-1}\right)$. Higher seed yield was due to higher growth and yield attributes viz., plant height (237.8 and 232.7 $\mathrm{cm}$, respectively), total dry matter production

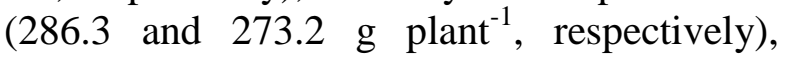
number of pods per plant (171.9 and 167.0, respectively) and seed yield (55.4 and 52.7 gplant $^{-1}$, respectively), compared to pigeon pea intercropped with green gram at 1:3 row ratio, where higher competition for resources between main and intercrop resulted in lower yield attributes. These results were in conformity with Rathod et al., (2004) and Rani and Raji (2010). Higher pigeon pea equivalent yield was recorded with pigeonpea + greengram $(1: 3)\left(3,394 \mathrm{kgha}^{-1}\right)$ followed by pigeonpea + blackgram $(1: 3)\left(3,370 \mathrm{~kg} \mathrm{ha}^{-1}\right)$ and lower was recorded with sole pigeon pea $\left(2,109 \mathrm{~kg} \mathrm{ha}^{-1}\right)$. The higher pigeon pea equivalent yield obtained with intercropping 
systems was attributed to better performance and yields of both the component crops compared to sole pigeonpea. Similar results were reported by Malik et al., (2013), Pandey et al., (2013) and Singh (2013).

\section{Interaction effect of drip irrigation levels and intercropping on growth and yield of pigeon pea}

The Interaction effect between drip irrigation levels and pigeon pea intercropping systems differed significantly with respect to plant height and total dry matter production (Table 2). Significantly higher when drip irrigation was scheduled to sole pigeon pea at 70

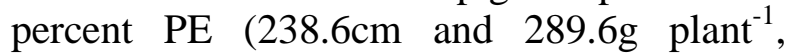
respectively) and total dry matter production was on par with drip irrigation scheduled at 50 per cent PE to sole pigeon pea $(283.0 \mathrm{~g}$ plant $\left.^{-1}\right)$. The plant height and total dry matter production were significantly higher compared to rainfed sole pigeon pea (191.3 $\mathrm{cm}$ and $222.8 \mathrm{~g}$ plant $^{-1}$, respectively).

The Interaction effect between drip irrigation levels and pigeon pea intercropping systems did not differ significantly with respect to pods per plant, seed yield per plant and seed yield per hector. Numerically, higher pods per plant and seed yield per plant (176.7 and $57.5 \mathrm{~g}$ plant ${ }^{-1}$,respectively) was recorded with drip irrigation was scheduled at 70 percent PE compared to rainfed sole pigeonpea (133.3 and $39.3 \mathrm{~g} \mathrm{plant}^{-1}$, respectively) and higher seed yield per hector was recorded with application of irrigation at 70 per cent PE through drip irrigation to sole pigeon pea $\left(2,198 \mathrm{~kg} \mathrm{ha}^{-1}\right)$ compared to rainfed sole pigeonpea $\left(1,613 \mathrm{kgha}^{-1}\right)$. Higher growth and yield parameters might due to the better utilization of available moisture, nutrient and lesser competition for resources leading to higher growth and yield contributing characters viz., plant height, total dry matter production per plant, pods per plant and seed yield per plant. Lower values were recorded with rainfed sole pigeon pea due to insufficient moisture availability at initial growth stages thereby reducing nutrient uptake which ultimately reflected in the lower number of plant height, total drymatter production, pods per plant and seed yield perplant.

Drip irrigation levels did not influence significantly the pigeon pea equivalent yield (PEY). Among the intercropping systems, pigeonpea intercropped with greengram or blackgram at row ratio of 1:3 recorded higher pigeon pea equivalent yield $\left(3,394 \mathrm{~kg} \mathrm{ha}^{-1}\right.$ and $3,370 \mathrm{~kg} \mathrm{ha}^{-1}$, respectively) compared to sole pigeon pea $\left(2,109 \mathrm{~kg} \mathrm{ha}^{-1}\right)$. Irrespective of drip irrigation levels, intercropping of pigeon pea with green gram or black gram at 1:3 row ratio recorded significantly higher PEY compared to sole pigeon pea and sole rainfed pigeonpea $\left(1,613 \mathrm{kgha}^{-1}\right)$. The higher pigeonpea equivalent yield obtained with intercropping systems was attributed to better performance and yields of both the component crops compared to sole pigeon pea. Similar results were reported by Malik et al., (2013) and Pandey et al., (2013).

\section{Water use efficiency of intercrops and intercropping system}

The water use efficiency was higher with drip irrigation provided at 50 per cent PE both togreen gram and black gram (Table 3) (7.22 and $5.61 \mathrm{~kg} \mathrm{ha}^{-1}-\mathrm{mm}$, respectively) compared to drip irrigation applied at 70 per cent $\mathrm{PE}$ (5.69 and $4.50 \mathrm{~kg} \mathrm{ha}^{-1}-\mathrm{mm}$, respectively). This was mainly due to the fact that at 50 percent PE, less quantity of irrigation water was provided compared to 70 percent $\mathrm{PE}$, thereby increasing the WUE. Intercropped blackgram recorded lower WUE compared to greengram which was mainly due to lower seed yield and higher crop duration compared to greengram resulting in extra irrigation at the time cropping period. 
Table.1 Yield and yield parameters of intercrops as influenced by drip irrigation levels

\begin{tabular}{|c|c|c|c|c|c|c|}
\hline \multirow{2}{*}{$\begin{array}{l}\text { Intercrop } \\
\text { Drip irrigation level }\end{array}$} & \multicolumn{3}{|c|}{ Green gram } & \multicolumn{3}{|c|}{ Black gram } \\
\hline & $\begin{array}{l}\text { No. of pods } \\
\text { plant }^{-1}\end{array}$ & $\begin{array}{l}\text { Seed yield } \\
\text { plant }^{-1}(\mathrm{~g})\end{array}$ & $\begin{array}{l}\text { Seed yield } \\
\left(\mathrm{kg} \mathrm{ha}^{-1}\right)\end{array}$ & $\begin{array}{l}\text { No. of pods } \\
\text { plant }^{-1}\end{array}$ & $\begin{array}{l}\text { Seed yield } \\
\text { plant }^{-1}(\mathrm{~g})\end{array}$ & $\begin{array}{c}\text { Seed yield } \\
\left(\mathrm{kg} \mathrm{ha}^{-1}\right)\end{array}$ \\
\hline $\mathrm{PE}_{1}-70 \% \mathrm{PE}$ & 17.3 & 11.8 & 1474 & 32.1 & 11.5 & 1411 \\
\hline $\mathrm{PE}_{2}-50 \% \mathrm{PE}$ & 15.7 & 10.9 & 1440 & 30.0 & 10.8 & 1374 \\
\hline $\begin{array}{l}\text { Test of significance } \\
\text { at } 5 \%\end{array}$ & NS & NS & NS & NS & NS & NS \\
\hline
\end{tabular}

PE : Pan evaporation

NS : Non significant

Market price $\left(\mathrm{q}^{-1} \mathrm{E}^{\mathrm{E}} \mathrm{g}\right.$ geon pea (5230), green gram (5375) and black gram (5200).

Table.2 Growth, yield parameters and yield of pigeon pea as influenced by drip irrigation levels and intercropping

\begin{tabular}{|c|c|c|c|c|c|c|}
\hline Treatment & $\begin{array}{l}\text { Plant } \\
\text { height } \\
\text { (cm) }\end{array}$ & $\begin{array}{l}\text { TDMP at } \\
\text { harvest } \\
\left.\text { (g plant }^{-1}\right)\end{array}$ & $\begin{array}{c}\text { Number } \\
\text { of pods } \\
\text { plant }^{-1}\end{array}$ & $\begin{array}{l}\text { Seed yield } \\
\text { plant }^{-1}(\mathrm{~g})\end{array}$ & $\begin{array}{c}\text { Seed yield } \\
\left(\mathrm{kg} \mathrm{ha}^{-1}\right)\end{array}$ & $\begin{array}{c}\text { PEY } \\
\left(\mathrm{kg} \mathrm{ha}^{-1}\right)\end{array}$ \\
\hline \multicolumn{7}{|l|}{ Drip irrigation levels (PE) } \\
\hline $\begin{array}{l}\text { PE1 ( } 70 \% \text { pan } \\
\text { evaporation) }\end{array}$ & $233.8^{\mathrm{a}}$ & $277.3^{\mathrm{a}}$ & $166.7^{\mathrm{a}}$ & $52.8^{\mathrm{a}}$ & $2010^{\mathrm{a}}$ & $2982^{a}$ \\
\hline $\begin{array}{l}\text { PE2 (50 \% pan } \\
\text { evaporation) }\end{array}$ & $232.2^{\mathrm{a}}$ & $271.4^{\mathrm{a}}$ & $165.2^{a}$ & $51.9^{\mathrm{a}}$ & $1997^{\mathrm{a}}$ & $2933^{a}$ \\
\hline S.Em. \pm & 1.84 & 1.70 & 3.99 & 1.27 & 58 & 122 \\
\hline \multicolumn{7}{|l|}{ Intercropping (IC) } \\
\hline $\begin{array}{l}\text { IC1 (Pigeon pea + green } \\
\text { gram 1:3) }\end{array}$ & $228.5^{c}$ & $263.5^{c}$ & $158.9^{\mathrm{a}}$ & $49.0^{\mathrm{a}}$ & $1898^{a}$ & $3394^{\mathrm{a}}$ \\
\hline $\begin{array}{l}\text { IC2 (Pigeon pea + black } \\
\text { gram 1:3) }\end{array}$ & $232.7^{\mathrm{b}}$ & $273.2^{b}$ & $167.0^{\mathrm{a}}$ & $52.7^{\mathrm{a}}$ & $1986^{\mathrm{a}}$ & $3370^{\mathrm{a}}$ \\
\hline IC3 (Sole pigeon pea) & $237.8^{\mathrm{a}}$ & $286.3^{a}$ & $171.9^{\mathrm{a}}$ & $55.4^{\mathrm{a}}$ & $2126^{\mathrm{a}}$ & $2109^{b}$ \\
\hline S.Em. \pm & 0.46 & 2.15 & 4.60 & 2.15 & 72 & 94 \\
\hline \multicolumn{7}{|l|}{ Interaction (PE x IC) } \\
\hline PE1 IC1 & $229.5^{d}$ & $265.6^{\mathrm{de}}$ & $159.1^{\mathrm{a}}$ & $49.9^{\mathrm{a}}$ & $1906^{\mathrm{a}}$ & $3421^{a}$ \\
\hline PE1 IC2 & $233.3^{c}$ & $276.6^{\mathrm{bc}}$ & $164.1^{\mathrm{a}}$ & $51.1^{\mathrm{a}}$ & $1925^{a}$ & $3328^{a}$ \\
\hline PE1 IC3 & $238.7^{\mathrm{a}}$ & $289.6^{\mathrm{a}}$ & $176.7^{\mathrm{a}}$ & $57.5^{\mathrm{a}}$ & $2198^{a}$ & $2198^{b}$ \\
\hline PE2 IC1 & $227.5^{\mathrm{e}}$ & $261.3^{\mathrm{e}}$ & $158.6^{\mathrm{a}}$ & $48.2^{\mathrm{a}}$ & $1891^{\mathrm{a}}$ & $3368^{a}$ \\
\hline PE2 IC2 & $232.1^{c}$ & $269.8^{\text {cd }}$ & $169.9^{\mathrm{a}}$ & $54.4^{\mathrm{a}}$ & $2047^{a}$ & $3412^{a}$ \\
\hline PE2 IC3 & $236.9^{b}$ & $283.0^{\mathrm{ab}}$ & $167.1^{\mathrm{a}}$ & $53.2^{\mathrm{a}}$ & $2053^{a}$ & $2020^{b}$ \\
\hline S.Em.土 & 0.43 & 1.90 & 6.25 & 2.50 & 78 & 155 \\
\hline \multicolumn{7}{|l|}{ Control } \\
\hline Rainfed sole pigeon pea & 191.3 & 222.8 & 133.3 & 39.3 & 1613 & 1613 \\
\hline S.Em. \pm & 1.54 & 3.32 & 5.93 & 2.45 & 87 & 150 \\
\hline C.D. $(P=0.05)$ & 4.74 & 10.2 & 18.29 & 7.56 & 267 & 463 \\
\hline
\end{tabular}

TDMP - Total dry matter production 
Table.3 Water use efficiency of drip irrigation system

\begin{tabular}{|c|c|c|c|c|}
\hline Drip irrigation level & $\begin{array}{l}\text { Water applied } \\
\text { through drip } \\
(\mathbf{m m})\end{array}$ & $\begin{array}{c}\text { Effective } \\
\text { rainfall }(\mathrm{mm})\end{array}$ & $\begin{array}{c}\text { Total water } \\
\text { applied }(\mathbf{m m})\end{array}$ & $\begin{array}{c}\text { Water use } \\
\text { efficiency } \\
\left(\mathrm{kg} \mathrm{ha}^{-1}-\right. \\
\text { mm })\end{array}$ \\
\hline \multicolumn{5}{|l|}{ Green gram } \\
\hline $\mathrm{PE}_{1}-70 \% \mathrm{PE}$ & 210.0 & 49.2 & 259.2 & 5.69 \\
\hline $\mathrm{PE}_{2}-50 \% \mathrm{PE}$ & 150.2 & 49.2 & 199.4 & 7.22 \\
\hline \multicolumn{5}{|l|}{ Black gram } \\
\hline $\mathrm{PE}_{1}-70 \% \mathrm{PE}$ & 239.2 & 74.4 & 313.6 & 4.50 \\
\hline $\mathrm{PE}_{2}-50 \% \mathrm{PE}$ & 170.5 & 74.4 & 244.9 & 5.61 \\
\hline \multicolumn{5}{|l|}{ Pigeon pea pulse intercropping system } \\
\hline Pigeon pea + green gram $(1: 3)$ at $70 \% \mathrm{PE}$ & 210.0 & 464 & 674.0 & 5.08 \\
\hline Pigeon pea + black gram (1:3)at $70 \%$ PE & 239.2 & 464 & 703.2 & 4.73 \\
\hline Sole pigeon peaat $70 \% \mathrm{PE}$ & 239.2 & 464 & 703.2 & 3.13 \\
\hline Pigeon pea + green gram $(1: 3)$ at $50 \%$ PE & 150.2 & 464 & 614.2 & 5.48 \\
\hline Pigeon pea + black gram (1:3)at $50 \%$ PE & 170.5 & 464 & 634.5 & 5.38 \\
\hline Sole pigeon peaat $50 \% \mathrm{PE}$ & 170.5 & 464 & 634.5 & 3.24 \\
\hline Rainfed sole pigeon pea (Control) & 000.0 & 527.6 & 527.6 & 3.06 \\
\hline
\end{tabular}

PE: Pan evaporation

Higher water use efficiency was recorded with drip irrigation provided at 50percent $\mathrm{PE}$ to pigeon pea intercropped with green gram at $1: 3$ row ratio $\left(5.48 \mathrm{~kg} \mathrm{ha}^{-1}-\mathrm{mm}\right)$ followed by drip irrigation at 50 per cent $\mathrm{PE}$ to pigeon pea intercropped with black gram at 1:3 row ratio $\left(5.38 \mathrm{~kg} \mathrm{ha}^{-1}-\mathrm{mm}\right)$ and sole pigeon pea $(3.24$ $\left.\mathrm{kg} \mathrm{ha}^{-1}-\mathrm{mm}\right)$. Lower water use efficiency was recorded in rainfed sole pigeon pea $(3.06 \mathrm{~kg}$ $\left.\mathrm{ha}^{-1}-\mathrm{mm}\right)$. The increased WUE was mainly due to considerable saving of irrigation water, more increase in pigeon pea equivalent yield and higher nutrient use efficiency. These results corroborated with the findings of Ramulu et al., (2006) and Vimalendran and Latha (2016).

It can be concluded that irrespective of drip irrigation levels at 50 or 70 per cent PE, pigeon pea + black gram or green gram at 1:3 row ratio intercropping systems recorded significantly higher pigeon pea equivalent yield $\left(3,412\right.$ and $3,421 \mathrm{~kg} \mathrm{ha}^{-1}$,respectively).

\section{References}

Anonymous, 2017, Area coverage, production and productivity of pulses in India and Karnataka. www.Indiastat.com.

Mahalakshmi, K., Avil Kumar, K., Devender Reddy, M. and Uma Devi, M., 2011, Response of rabi pigeonpea to different levels of drip irrigation. J. Res. ANGRAU, 39(4):101-103.

Malik, J. K., Singh, R., Thenua, O. V. S. and Kumar, A., 2013, Response of pigeon pea [Cajanus cajan (L.) Millsp.] + greengram (Vigna radiate L.) intercropping system to phosphorus and biofertilizers. Legume Res., 36 (4): 323330.

Pandey,I.B.,Singh,S.K.andTiwari,S.,2013,Inte gratednutrientmanagementforsustainingt he productivity of pigeon pea [Cajanus cajan (L.) Millsp.] based intercropping systems under rainfed condition. Indian J. Agron., 58 (2):192-197.

Parmar, P. P. and Thanki, J. D., 2007, Effect 
of irrigation, phosphorus and biofertilizer on growth and yield of rabigreen gram (Vigna radiate L.) under South Gujarat condition. Crop Res., 34 (1-3):100-102.

Ramulu, V., Suresh, K. and Balaguravaiah, D., 2006, Effect of irrigation schedules and sowing methods on rabi pigeon pea [Cajanus cajan (L.) Millsp.] in NSP left Canal Command of A. P. J. Water Mgt., 14 (2): 125-127.

Rani, B. P. and Raji, D. R., 2010, Performance of pigeon pea in sole and inter cropping system in Vertisols of Krishna - Godavari zone in Andhra Pradesh. Indian J. Agric. Res., 44 (3): 225- 228.

Rathod, P. S., Halikatti, S. I., Hiremath, S. M. and Kajjidoni, S. D., 2004, Comparative performance of pigeon pea based intercropping system in Northern transition zone of Karnataka. Karnataka J. Agric. Sci., 17: 203-206.

Sankaran, S. and Rangasamy, A., 1990, Farming System Research In :
Agronomic Research Towards Sustainable Agriculture, Indian Society of Agronomy, IARI, New Delhi, pp. 6980.

Singh, R., Malik, J. K., Thenua. V. S. and Jat, H. S., 2013, Effect of phosphorus and bio fertilizer on productivity, nutrient uptake and economics of pigeon pea + green gram inter cropping system. Legume Res., 36 (1): 41 - 48.

Solanki, R. M., Sagarka, B. K., Dabhi, B. M., Shaikh, M. A. and Gohil, B. S., 2010, Response of chickpea to drip irrigation and integrated nutrient management under Saurashtra region of Gujarat. Agriculture towards a New Paradigm of Sustainability, ISBN: 978-93-83083-640 .

Vimalendran, L. and Latha, K.R., 2016, Yield, nutrient uptake water use and water use efficiency of pigeon pea [Cajanus cajan (L.) Millsp.] under drip fertigation system. J. Applied Natural Sci., 6(1): 457-462.

\section{How to cite this article:}

Anandkumar, H. N., S. C. Alagundagi, G. B. Shashidhara and Kuligod, V. B. 2020. Impact of Drip Irrigation Levels on Pigeon Pea Based Intercropping Systems with Pulses in Malaprabha Command Area. Int.J.Curr.Microbiol.App.Sci. 9(09): 2617-2623. doi: https://doi.org/10.20546/ijcmas.2020.909.327 